\title{
Phytoprotection
}

\section{Abiotic and biotic factors affecting Rhagoletis mendax [Diptera :Tephritidae] populations in eastern Canadian lowbush blueberry fields}

\section{P.S. Geddes, J.-P.R. LeBlanc et W.N. Yule}

Volume 73, numéro 2, 1992

URI : https://id.erudit.org/iderudit/706022ar

DOI : https://doi.org/10.7202/706022ar

Aller au sommaire du numéro

Éditeur(s)

Société de protection des plantes du Québec (SPPQ)l

ISSN

0031-9511 (imprimé)

1710-1603 (numérique)

Découvrir la revue

Citer cet article

Geddes, P., LeBlanc, J.-P. \& Yule, W. (1992). Abiotic and biotic factors affecting Rhagoletis mendax [Diptera :Tephritidae] populations in eastern Canadian lowbush blueberry fields. Phytoprotection, 73(2), 73-78.

https://doi.org/10.7202/706022ar
Résumé de l'article

Une étude a été effectuée en Nouvelle-Ecosse et au Nouveau-Brunswick au Canada, afin d'identifier des facteurs naturels de régulation, tels que l'acidité du sol et la présence de mauvaises herbes, qui pourraient influencer l'occurrence de populations de la mouche de l'airelle (Rhagoletis mendax) dans les bleuetières naines commerciales (Vaccinium angustifolium). Les niveaux observés d'acidité du sol n'ont pas été identifiés comme un facteur régissant la distribution et la mortalité des larves et des pupes du R. mendax. Les mouvements migratoires des adultes ont été affectés par la pratique culturale du brûlage des champs de bleuets aux deux ans et il en résulte que les adultes, émergeant de la portion brûlée des champs, migrent vers les zones en production. Une corrélation positive entre l'intensité de la pousse des mauvaises herbes indigènes et les niveaux d'infestation de la mouche de l'airelle a été démontrée. 


\title{
Abiotic and biotic factors affecting Rhagoletis mendax [Diptera: Tephritidae] populations in eastern Canadian lowbush blueberry fields
}

\author{
Paul S. Geddes ${ }^{1}$, Jean-Pierre R. Le Blanc ${ }^{1,2}$, and William N. Yule ${ }^{3}$
}

Received 1991-08-14; accepted 1992-07-24

An investigation was carried out in Nova Scotia and New Brunswick, Canada, to identify natural regulatory factors, such as soil acidity and weed incidence, that could influence the occurrence of blueberry maggot (Rhagoletis mendax) populations in commercial lowbush blueberry fields (Vaccinium angustifolium). Over the range observed, the soil acidity had no detectable influence on the distribution and mortality of $R$. mendax larvae and pupae. Adult migrational patterns were affected by the cultural practice of burning on alternate years causing the emerging adults of burned fields to move towards areas in production. There was also a positive correlation between the growth intensity of indigenous weeds and blueberry maggot infestation levels.

Geddes, P.S., J.-P. R. Le Blanc, and W.N. Yule. 1992. Abiotic and biotic factors affecting $R$ hagoletis mendax [Diptera: Tephritidae] populations in eastern Canadian lowbush blueberry fields. PHYTOPROTECTION 73: 73-78.

Une étude a été effectuée en Nouvelle-Écosse et au Nouveau-Brunswick au Canada, afin d'identifier des facteurs naturels de régulation, tels que l'acidité du sol et la présence de mauvaises herbes, qui pourraient influencer l'occurrence de populations de la mouche de l'airelle (Rhagoletis mendax) dans les bleuetières naines commerciales (Vaccinium angustifolium). Les niveaux observés $d^{\prime}$ acidité du sol n'ont pas été identifiés comme un facteur régissant la distribution et la mortalité des larves et des pupes du $R$. mendax. Les mouvements migratoires des adultes ont été affectés par la pratique culturale du brûlage des champs de bleuets aux deux ans et il en résulte que les adultes, émergeant de la portion brûlée des champs, migrent vers les zones en production. Une corrélation positive entre l'intensité de la pousse des mauvaises herbes indigènes et les niveaux d'infestation de la mouche de l'airelle a été démontrée.

\section{INTRODUCTION}

1. A.D. Pickett Entomological Museum and Research Laboratory, Department of Biology. Nova Scotia Agricultural College, P.O. Box 550, Truro, Nova Scotia, Canada B2N $5 E 3$

2. Author to whom correspondence should be addressed

3. Department of Entomology, Macdonald Campus of McGill University, 21111

Lakeshore Road, Sainte-Anne-de-Bellevue, Québec, Canada, H9X 3V9
The blueberry maggot (Rhagoletis mendax Curran) [Diptera:Tephritidae] has been recognized as a pest of lowbush blueberries (Vaccinium angustifolium Aiton) in Eastern Canada since 1930 (Brittain and Pickett 1933). Despite the rapid expansion of the commercial blueberry industry in recent years, the distribution of this species has remained relatively localized within eastern Canada (Geddes et al. 1987). 
There is some evidence to suggest that soil $\mathrm{pH}$ may play a part in regulating the distribution of certain tephritid species. Darby and Kapp (1934) proposed that the distribution of the Mexican fruit fly [Anastrepha ludens (Loew)] was influenced by the sensitivity of larvae to acidic soil conditions although Baker et al. (1944) cited evidence to counter this claim. In eastern Canada, lowbush blueberries are normally found in more acidic soils than in northeastern United States (Hall and Aalders 1983; Trevett et al. 1972).

It has been suggested that the cultural practice of burning, employed to prune blueberry plants, may also be a significant mortality factor. The thorough burning of fields and the routine removal of alternative host plants such as bunchberry (Cornus canadensis L.) will reduce population levels by depriving females of oviposition sites (Miller 1979). There is also evidence to suggest that flies will disperse from fields that have been burned to adjacent fields that are in production (Wood 1980).

The objectives of this study were: 1) to determine if a relationship exists between the soil acidity and the occurrence of $R$. mendax in eastern Canada, 2) to verify if burned blueberry fields were a source of blueberry maggot infestation for adjacent production fields, and 3) to examine an hypothetical relationship between weed cover and $R$. mendax infestation levels.

\section{MATERIALS AND METHODS}

\section{Soil acidity}

Several commercial lowbush blueberry fields were selected for a 2-yr study from different geographical areas and soiltypes, with a wide range of $R$. mendaxinfestation levels (Geddes et al. 1989). Lowbush blueberries grow on humo-ferric podzols (Eaton and Patriquin 1988). Location and field details are presented in Table 1. Six fields were chosen in the first yr, four in Nova Scotia and two in New Brunswick. In the second yr, 13 fields were selected, nine in Nova Scotia and four in New Brunswick. A 4-ha test plot was established within the crop section of each field. Each plot was further subdivided into 14 blocks in the first yr and 16 blocks in the second $y r$.

Table 1. Location details of blueberry fields selected for the 2-yr soil acidity study

\begin{tabular}{llll}
\hline $\begin{array}{l}\text { Nearest } \\
\text { locality }\end{array}$ & $\begin{array}{l}\text { Provincial } \\
\text { county }\end{array}$ & $\begin{array}{l}\text { Canadian } \\
\text { province }\end{array}$ & $\begin{array}{l}\text { Year } \\
\text { used }\end{array}$ \\
\hline $\begin{array}{lll}\text { Dorchester South } \\
\text { West Memramcook }\end{array}$ & Westmorland & New Brunswick & 2 \\
Dorchester North & Westmorland & New Brunswick & 2 \\
Shediac & Westmorland & New Brunswick & 2 \\
Richibucto & Westmorland & New Brunswick & 1 \\
Oxford & Kent & New Brunswick & 1,2 \\
Middle Musquodoboit & Cumberland & Nova Scotia & 2 \\
East Gore & Halifax & Nova Scotia & 2 \\
Debert & Hants & Nova Scotia & 1 \\
Wittenberg & Colchester & Nova Scotia & 2 \\
Glenholme & Colchester & Nova Scotia & 2 \\
Glencoe & Colchester & Nova Scotia & 2 \\
New Canaan Mountain & Pictou & Nova Scotia & 1 \\
Parrsboro & Cumberland & Nova Scotia & 2 \\
Folly Lake & Cumberland & Nova Scotia & 1,2 \\
Central North River & Colchester & Nova Scotia & 1 \\
Rawdon & Colchester & Nova Scotia & 2 \\
& Hants & Nova Scotia & 2 \\
\hline
\end{tabular}


Blueberry maggot population levels were measured by sampling both adult and larval stages. Adult numbers were determined by installing one baited Pherocon ${ }^{\circledR}$ AM trap (Zoëcon Corporation, Palo Alto, California, CA 94304) $(23 \mathrm{~cm} \mathrm{x}$ $28 \mathrm{~cm}$ ) within each block of the test plots. In the first yr, all traps were installed in an inverted " $V$ » position (folded to form a $90^{\circ}$ angle with the apex pointing up and the sticky yellow surface facing downward). Trap captures were recorded weekly for a period of $3 \mathrm{wk}$. All traps were installed in an upright " $V$ » position during the second yr of field trials, as this position was found to be more efficient for capturing flies (Geddes et al. 1989). Such an installation causes the yellow sticky surface to be more visible to foraging flies because it is thus on the external sides of the "V". Fly captures were recorded once a week for 6 wk and all traps were replaced with new ones after 3 wk. During the final week of trapping, $1-L$ samples of ripe blueberry fruits were randomly collected within each block of the test plots. The number of larvae present in each sample was determined using the boiling technique of Neilson et al. (1984).

An estimate of the soil $\mathrm{pH}$ within each test plot was made from soil samples collected from individual blocks using a soil auger. Each sample consisted of a composite of 12 cores measuring $5 \mathrm{~cm}$ in depth and $2 \mathrm{~cm}$ in diam. Samples were placed in plastic bags and stored at $5^{\circ} \pm 1^{\circ} \mathrm{C}$ until laboratory analysis. All analyses were performed as soon as feasible, however, the storage period never exceeded $3 \mathrm{wk}$. In the first yr, one set of soil samples was collected during the first wk of the field work. In the second $y r$, samples were collected during the first, third, and sixth wk. Soil $\mathrm{pH}$ measurements were made using a research grade digital $\mathrm{pH}$ meter (Orion Model 811, Orion Research Inc., Cambridge, Massachusetts, MA 02139) with a two-point electrode standardization. This provided a $\mathrm{pH}$ accuracy of \pm 0.003 units. To compensate for the effect of soluble soil salts, all samples were measured in a $0.01 \mathrm{M}$ solution of calcium chloride at a ratio of one part soil to two parts $\mathrm{CaCl}_{2}$ (Peech 1965). Final pH measurements were rounded off to the nearest 0.01 unit.
The relationship between soil $\mathrm{pH}$ and blueberry maggot population levels was established using a Spearman rank correlation analysis (Daniel 1978). The three series of soil samples collected during the second yr of field trials were submitted to a Kruskal-Wallis one-way analysis of variance (Sokal and Rohlf 1981) to assess the relative stability of the soil $\mathrm{pH}$ during the growing season.

\section{Fly migration}

This experiment was carried out in two Nova Scotia lowbush blueberry fields (Glenholme and Parrsboro sites) during the second growing season. Both fields consisted of adjacent burned and unburned (crop) sections and had histories of blueberry maggot infestation. To detect fly migration or movement between field sections at each site, an experimental plot measuring 8 ha and overlapping the burned and unburned (crop) sections of the field (i.e., 4 ha per section) was marked off within each field. A total of 32 baited Pherocon AM traps were installed in a "V" position within each 8 ha field (i.e. 16 per section, in four rows of four traps each). Trap captures were recorded weekly for a 6 -wk period with all traps being replaced after the third wk. During the final week of the trial, 1-L samples of blueberry fruit were collected randomly within a 15-m radius of each trap. Larval counts were determined using the boiling technique of Neilson et al. (1984).

A nested analysis of variance (Sokal and Rohlf 1981) was used to determine if the number of fly captures differed amongst traps within each row, rows within each section, and between the burned and crop sections.

\section{Weed incidence}

Weeds typically associated with eastern Canada lowbush blueberry fields were listed and described by Jackson and Hall (1983). This investigation utilized the 13 fields selected for the soil acidity investigation (see above for block description). Trap capture and larval count data were retained and assessments of indigenous weed cover and blueberry colony cover were made. The 16 blocks ( 0.25 ha) of each plot ( $4 \mathrm{ha}$ ) were visually monitored for both assessments. Blocks with sparse or no weed cover $(0-35 \%)$ were scored one, those with moderate weed cover (36- 
$70 \%$ ) had a score of two, and those with dense weed cover (71-100\%) had a score of three. The same technique was used again to estimate the blueberry colony cover. Because of the presence of barren patches, the combined vegetation cover estimates for a given block did not necessarily totalled $100 \%$ coverage. For both assessments, the average score of each test plot was calculated and all scores were ranked along with adult trap captures and larval counts.

All data were analyzed using a Spearman rank correlation and calculated values were adjusted for ties (Daniel 1978). This procedure was used for the following five sets of variables: adult trap captures and blueberry cover, adult trap captures and weed cover, larval counts and blueberry cover, larval counts and weed cover, and blueberry cover and weed cover.

\section{RESULTS AND DISCUSSION}

\section{Soil acidity}

The rank correlation coefficient for soil $\mathrm{pH}$ and the number of $R$. mendax larvae and adults was not significant (Table 2). The coefficient for fly captures and larval counts was significant $(P \leq 0.01)$, indicating no irregularities in the $R$. mendax population or stage-sampling techniques. The $\mathrm{pH}$ values for the three series of soil samples collected in the second yr did not differ significantly. Although soil acidity was relatively stable during this research trial, Brady (1974) noted that soil pH measurements may vary with the amount of precipitation received.

Lowbush blueberries occur all over eastern Canada in acidic soils of a $\mathrm{pH}$ generally ranging from 4.0 to 5.5 (Hall and trap captures or larval counts
Aalders 1983). Our soil $\mathrm{pH}$ results ranged from 3.68 to 4.24 in the first $y r$, and 3.38 to 4.54 in the second yr. These values are below the 4.5 to 5.0 range recommended for optimal commercial production of blueberries (Trevett et al. 1972). A previous study of the chemical and physical properties of ripening lowbush blueberries revealed that fruit $\mathrm{pH}$ reaches a maximum of ca. 3.67 (Ismail and Kender 1974). Based on all these considerations and given that the four maggot instars occur in the ripening fruits, $R$. mendax larvae should be able to tolerate the acidic soil conditions of most commercial lowbush blueberry fields.

\section{Fly migration}

The number of $R$. mendax fly captures in the burned and crop sections differed significantly $(P \leq 0.05)$ for both of the test fields (Table 3). The number of fly captures also differed significantly $(P \leq 0.01)$ between the traps within each row and between the rows of each section of the Glenholme field. These variables did not differ significantly in the Parrsboro field which was (mistakenly) sprayed with carbaryl $25 \%$ WP $\left(1.1 \mathrm{~kg}^{2}\right.$ a.i. ha $\left.{ }^{-1}\right)$ by the field owner. This action coincided with a dramatic drop in the number of blueberry maggot captures when adult emergence should have been reaching its peak. The effectiveness of this application was further demonstrated when the extraction of $16 \mathrm{~L}$ of blueberry fruits resulted in the detection of only one larva. Samples collected from the unsprayed Glenholme field yielded an average of $23.5 \pm 8.5$ larvae per litre of fruits.

Weekly data of trap captures in the Glenholme and Parrsboro fields indicate a general fly migration from the burned section to the crop section over the mo-

Table 2. Spearman rank correlation coefficient $\left(\boldsymbol{r}^{s}\right)$ values for soil $\mathrm{pH}$ and Rhagoletis mendax adult

\begin{tabular}{lcc}
\hline Parameters & $\begin{array}{l}\text { Year 1 } \\
(\mathrm{n}=6)\end{array}$ & $\begin{array}{c}\text { Year 2 } \\
(\mathrm{n}=13)\end{array}$ \\
\hline Soil $\mathrm{pH}$ - number of adults & $-0.49 \mathrm{~ns}$ & $-0.32 \mathrm{~ns}$ \\
Soil pH - larval counts & $-0.36 \mathrm{~ns}$ & $-0.19 \mathrm{~ns}$ \\
Number of adults - larval counts & $0.99^{* *}$ & $0.84^{* *}$
\end{tabular}

\footnotetext{
${ }^{* *}$ Significant at $P \leq 0.01$; ns: non-significant.
} 
Table 3. Calculated $F$ values for total $R$ hagoletis mendax adults captured on baited Pherocon AM traps in the burned and crop sections of two Nova Scotia commercial lowbush blueberry fields over a 6-wk period

\begin{tabular}{lcr}
\hline & \multicolumn{2}{c}{ Field location } \\
\cline { 2 - 3 } Source of variation & Glenholme & Parrsboro $^{\text {a }}$ \\
\hline Among sections & $6.125^{*}$ & $6.243^{*}$ \\
Among rows within sections & $4.172^{* *}$ & $0.774 \mathrm{~ns}$ \\
Among traps within rows & $3.245^{* *}$ & $0.765 \mathrm{~ns}$ \\
& & 555.0 \\
Total captures, crop section & 6244.0 & 5.8 \\
Mean captures, crop section & 65.0 & 913.0 \\
Total captures, burned section & 4209.0 & 9.5 \\
Mean captures, burned section & 43.8 & \\
\hline
\end{tabular}

ansecticide applied during second wk.

*Significant at $\mathrm{P} \leq 0.05 ;{ }^{* *}$ significant at $\mathrm{P} \leq 0.01$; ns: non-significant.

Table 4. Spearman rank correlation coefficient values for the number of Rhagoletis mendax adults and larvae and the extent of blueberry and weed covers

\begin{tabular}{lc}
\hline Parameters & $r^{s}$ \\
\hline Adult captures and blueberry cover & $-0.79{ }^{* *}$ \\
Adult captures and weed cover & $0.54^{*}$ \\
Larval counts and blueberry cover & $-0.95{ }^{* *}$ \\
Larval counts and weed cover & $0.73{ }^{* *}$ \\
Blueberry growth and weed cover & $-0.91{ }^{* *}$ \\
${ }^{*}$ Significant at $P \leq 0.05 ;{ }^{* *}$ significant at $P \leq 0.01$.
\end{tabular}

nitored period. Because of the unplanned insecticide application, the crop section total captures of the Parrsboro field may be misleading, i.e. less than that of the burned section. In the Glenholme field, however, movement was also detected in other directions as well. This is noted by the significant $F$ values for both variations among rows within sections and among traps within rows (Table 3 ). This discrepancy may be explained by the random foraging behaviour of newly emerged flies (Prokopy 1977; Prokopy and Owens 1978).

\section{Weed incidence}

Results from the weed incidence study revealed a highly significant correlation $(P \leq 0.01)$ between all pairs of variables, except trap captures and weed incidence which were significant only at $P \leq 0.05$
(Table 4). The negative correlation between weed incidence and blueberry density is in agreement with earlier reports of indigenous weeds competing directly with blueberry plants for space, light, moisture, and soil nutrients (Jackson and Hall 1983). The correlation between weed scores and $R$. mendax density levels also supports previous observations that blueberry maggot flies utilize weeds for shelter from wind and adverse weather conditions (Lathrop and Nickels 1932; Wood 1979). These results, therefore, give further evidence that controlling weeds in commercial blueberry fields should reduce $R$. mendaxpopulation levels.

\section{ACKNOWLEDGEMENTS}

Part of a thesis submitted to the Faculty of Graduate Studies and Research of McGill University by P.S. Geddes in partial fulfillment of the requirements for the degree of Master of Science. Financial support was provided by an Agriculture Canada grant-in-aid to J.-P. R. Le Blanc.

\section{REFERENCES}

Baker, A.C., W.E. Stone, C.C. Plummer, and M. McPhail. 1944. A review of studies on the Mexican Fruitfly and related Mexican species. Miss. Publ. U.S. Dept. Agric. 531. 155 pp. 
Brady, N.C. 1974. The nature and properties of soils. 8th ed. MacMillan Publ. Co., New York. $639 \mathrm{pp}$.

Brittain, W.H., and A.D. Pickett. 1933. Injurious insects of Nova Scotia. Part I. Fruit insects. N.S. Dep. Agric. Bull. 12, p. 119-121.

Daniel, W.W. 1978. Applied nonparametric statistics. Houghton Mifflin Company, Boston. 503 pp.

Darby, H.H., and E.M. Kapp. 1934. Studies on the Mexican fruit fly, Anastrepha ludens (Loew). Tech. Bull. U.S. Dep. Agric. 444. 20 $\mathrm{pp}$.

Eaton, L.J., and D.G. Patriquin. 1988. Inorganic nitrogen levels and nitrification potential in lowbush blueberry soils. Can. J. Soil Sci. 68: 63-75

Geddes, P.S., J.-P. R. Le Blanc, and W.N. Yule. 1987. The blueberry maggot, Rhagoletis mendax [Diptera: Tephritidae], in eastern North America. Rev. Entomol. Quebec 32: 16-24.

Geddes, P.S., J.-P. R. Le Blanc, K.L. Flanders, and H.Y. Forsythe Jr. 1989. Installation of baited Pherocon AM traps for monitoring adult populations of Rhagoletis mendax [Diptera:Tephritidae] in lowbush blueberry fields. Environ. Entomol. 18: 510-512.

Hall, I.V., and L.E. Aalders. 1983. Lowbush blueberry production and management Pages 3-19 in Lowbush Blueberry Production. Agric. Can. Publ. 1477

Ismail A.A., andW.J. Kender. 1974. Physical and chemical changes associated with the development of the lowbush blueberry fruit Vaccinium angustifolium Ait. Agric. Exp. Stn., Univ. of Maine, Orono. Life Sciences Tech. Bull. 70. 13 pp.

Jackson, L.P., and I.V. Hall. 1983. Weeds. Pages 15-19 in Lowbush Blueberry Production. Agric. Can. Publ. 1477.

Lathrop, F.H., and C.B. Nickels. 1932. The biology and control of the blueberry maggot in Washington County Maine. USDA Tech. Bull. 275. 76 pp.

Miller, W.E. 1979. Fire as an insect management tool. Bull. Environ. Soc. Am. 25: 132 140.

Neilson, W.T.A., A.D. Knowlton, and M. Fuller. 1984. Capture of blueberry maggot adults, Rhagoletis mendax [Diptera: Tephritidae] on Pherocon AM traps and on tartar red dark spheres in lowbush blueberry fields. Can. Entomol. 116: 113-118.

Peech, M. 1965. Hydrogen-ion activity. Pages 914-926 in C.A. Black (ed.), Methods of Soil Analysis. Part 2. Chemical and microbial properties. American Society of Agronomy, Madison, Wisconsin.

Prokopy, R.J. 1977. Stimuli influencing trophic relations in Tephritidae. Colloq. Int. Cent Nat. Res. Sci. 265: 305-336.
Prokopy, R.J., and E.D. Owens. 1978. Visual generalist vs. visual specialist phytophagous insects: host selection behavior and application to management. Entomol. Exp. Appl. 24: 609-620.

Sokal, R.R., and F.J. Rohlf. 1981. Biometry. The principles and practices of statistics in biological research. 2nd ed. W.H. Freeman and Company, New York. 859 pp.

Trevett, M.F., P.N. Carpenter, and R.E. Durgin. 1972. Regulating soil acidity in unplowed lowbush blueberry fields. Coop. Ext. Service, Univ. of Maine, Orono. Bull. 568. 12 pp.

Wood, G.W. 1979. Insects. Pages 20-28 in Lowbush Blueberry Production. Agric. Can. Publ. 1477.

Wood, G.W. 1980. Dispersal of blueberry maggot adults as a major source of infestation in first crop blueberry fields. $1979 \mathrm{Re}$ search Summary. Agric. Can. Res. Stn., Fredericton, N.B. p. 106-108. 